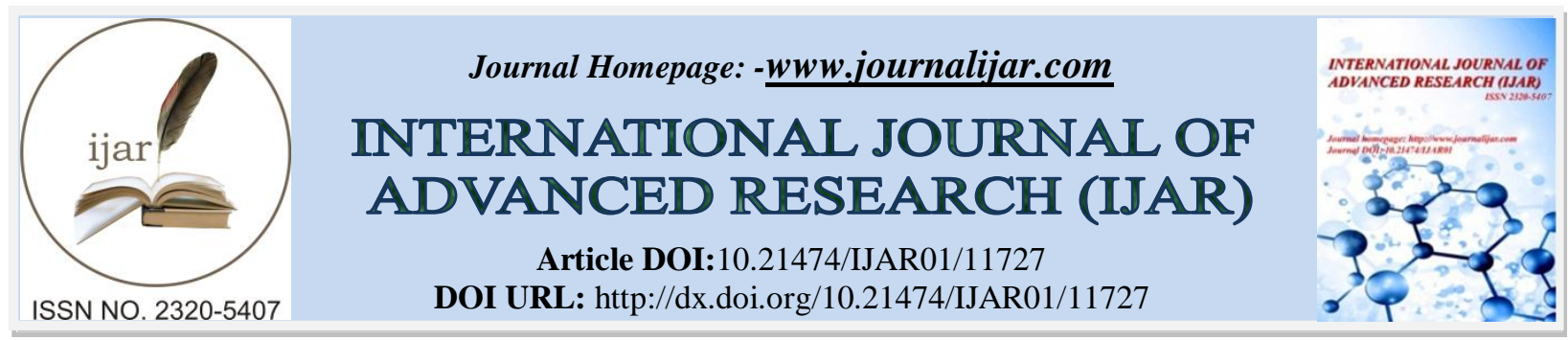

RESEARCH ARTICLE

\title{
DIVERSITY OF THE GENUS CHROOCOCCUS NAGELI (CHROOCOCCACEAE, CYANOBACTERIA) FROM SOUTHERN WESTERN GHAT REGIONS OF KERALA, INDIA
}

Manu Philip and V.V. Radha Krishnan

Genetics and Plant Breeding, Department of Botany, University of Calicut, Kerala, India-673635.

\section{Manuscript Info}

Manuscript History

Received: 15 July 2020

Final Accepted: 18 August 2020

Published: September 2020

Key words:-

Epilithic, Epactiphytic, Symbiotic,

Chroococcales, Forests

\section{Abstract}

Cyanobacteria are one of the ecologically and economically relevant microorganisms that perform both photosynthesis and nitrogen fixation. Among them, unicellular species such as Chroococcus have immense applications in biotechnological as well as agricultural fields. Due to the cellular simplicity, Chroococcus was easy to isolate, cultivate and multiply. They are good fixators of atmospheric nitrogen, and also performs oxygen production. Kerala forests are one of the least explored area with respect to cyanobacteria. This study aims at collecting divers Chroococcus species from selected forest areas of Kerala. While the investigation, a total of eleven Chroococcus species found from selected forest areas.

Copy Right, IJAR, 2020,. All rights reserved.

\section{Introduction:-}

Cyanobacteria are prokaryotic photosynthetic organisms capable of fixing atmospheric nitrogen. They are the inevitable connecting link between prokaryotes and eukaryotes. Cyanobacteria are small and usually unicellular. They are often seen as colonies, which are large enough for naked eye vision. According to the recent evidences it is believed that their present diversity was achieved more than 3.5 billion years ago. Now cyanobacteria are cosmopolitan in distribution mainly because of their adaptability to all type of environmental conditions. Cyanobionts are the typical examples of organisms that forms symbiotic association to survive in difficult conditions. Certain works on cyanobacteria proves that these organisms played a major role in the accumulation of oxygen in the primitive Earth. Cyanobacteria are mainly found in 3 different forms. They are unicellular, unbranched filamentous and branched filamentous. Unbranched filamentous are of two types, non-heterocystous and heterocystous. This work is focused on the diversity of unicellular cyanobacterial genus namely Chroococcus. Chroococcus comes under the order Chroococcales and family Chroococcaceae. Cyanobacterial diversity is considered as an indicator of the strength of an ecosystem. High diversity of cyanobacteria illustrate the richness of that environment.

\section{Materials And Methods:-}

Study area was selected forest regions Kerala from Wayanad, Kozhikode, Palakkad, Thrissur, Idukki. Major forests of these Districts were explored during this study period (May-August 2018). Work is focused on the forest areas, which comes under Western Ghats. Samples were collected from soil, rock, bark of trees and also from water bodies and streams. Sites were chosen on the basis of the visual appearance of cyanobacterial mass on these areas.

\section{Corresponding Author:-Manu Philip}

Address:-Genetics and Plant Breeding, Department of Botany, University of Calicut, Kerala, India673635 . 
Specimens were collected in collection bottles using scalpels, needle and spatula. Each specimen was provided with a voucher number. Collected samples were cleaned by using distilled water, cultured in BG-11 medium (Rippka et al., 1979) and deposited in germplasm collection of cyanobacteria at Cyanobacterial Diversity Division, Department of Botany, University of Calicut. The collected specimens were examined by using Leica DM 1000 compound microscope and microphotographs of each were taken. Photographed specimens were identified by using standard taxonomic manuals of Desikachary (1959), Anand (1989) and Komarek (2014).

\section{Result:-}

A Total of eleven species from Chroococcus genus were reported during this work. Among them Most of the specimens were collected from rocks, some were from soil. The dominating type was epilithic. Observed cyanobacterial species are the following;

\section{Chroococcus indicus Zeller}

Colonies microscopic, gelatinous, mucilage brownish-green in colour, sometimes diffluent; cells spherical to oval in shape, with sheath 10-10.5 $\mu \mathrm{m}$ in length, 7.6-8.1 $\mu \mathrm{m}$ in breadth, without sheath 4.4-5.7 $\mu \mathrm{m}$ broad and 4.2-4.6 $\mu \mathrm{m}$ long; sheath firm, hyaline, unlamellate, 0.7-2.1 $\mu \mathrm{m}$ thick; granules present, not prominent. Collected specimens were saphophytic. (L)

\section{Chroococcus turgidus (Kutzing) Nageli}

Colonies microscopic, usually 2-8 celled, sometimes up to 32 celled, without wide enveloping mucilage; cells widely oval to spherical, hemispherical or in the form of segment of a sphere after division, green, intensely green, yellowish or olive green in colour, 8-32 $\mu \mathrm{m}$ in diameter; sheath thick, firm, lamellated or unlamellated, colourless, up to $10 \mu \mathrm{m}$ thick; granules present, occasionally prominent. Collected specimens were epilithic. (J)

\section{Chroococcus pallidus (Nageli) Nageli}

Colonies usually microscopic, gelatinous, colourless or yellowish, free or mixed with other algae; cells in a firm sheath, hyaline or yellowish brown coloured, 2-4 cells in a sheath, not lamellate or rarely lamellate, thick, 4-8 $\mu \mathrm{m}$ wide; cells spherical, after division hemispherical to spherical, olive green or pale blue green in colour, single or in pairs, $8-14 \mu \mathrm{m}$ in diameter. Collected specimens were epilithic. (F)

\section{Chroococcus cohaerens (Brebisson) Nageli}

Cells in 2-8 celled groups to forming colonies, gelatinous, normally groups of cells with individual, thin, unstratified mucilaginous mass; sheath or envelop hyaline, not lamellate, thick; cells spherical, later hemispherical or irregular, with envelop 6-7.5 $\mu \mathrm{m}$ in diameter, without envelop 4-6.8 $\mu \mathrm{m}$ in diameter, pale blue green, olive green or yellowish brown in colour; granules present, not prominent. Collected specimens were epilithic. (A)

\section{Chroococcus minutus (Kutzing) Nageli}

Cells solitary, microscopic, few celled, usually 2-8 cells, enclosed in a mucilaginous mass; cells spherical or hemispherical, pale blue green, yellow or grey in colour, 6.8-11 $\mu \mathrm{m}$ in diameter; granules present, sometimes prominent; sheath thick, firm, diffluent towards margin, hyaline, usually unlamellate, $4-8 \mu \mathrm{m}$. collected specimens were epiphloeophytic. (B)

\section{Chroococcus minutus var. thermalis copeland}

Cells solitary, microscopic, few celled, usually 2-8 cells, mucilaginous; cells spherical or hemispherical, pale blue green, yellow or olive green in colour, 7-12 $\mu \mathrm{m}$ in diameter; granules present, prominent; sheath comparatively thick, firm, not diffluent towards margin, hyaline, unlamellate, 1.5-3 $\mu \mathrm{m}$. Collected specimens were epilithic. (C)

\section{Chroococcus mipitanensis (Wolszynska) Geitler}

Cells in groups, microscopic, few celled, usually 4-16 cells, mucilaginous; cells spherical, hemispherical and rarely irregular, blue green in colour, 2.5-6 $\mu \mathrm{m}$ in diameter; usually granules absent, not prominent if it present; sheath thick, firm, hyaline to light green in colour, not diffluent, unlamellate. Collected specimens were epactiphytic. (D \& E)

\section{Chroococcus quaternarius M.D. Zalessky}

Colonies microscopic, forming nest like thallus composed of subcolonies with 2-8 more or less clustered cells, packet like arrangement, mucilaginous, mucilage colourless; cells more or less spherical, hemispherical after 
division, later irregular rounded, brownish green or blue green in colour, 12-20 $\mu \mathrm{m}$ in diameter; sheath thick, firm, unlamellate, slightly diffluent towards the periphery. Collected specimens were epiphytic. (G)

\section{Chroococcus subnudus (Hansgirg) C. Cronberg \& J. Komarek}

Colonies microscopic, usually 2-4 celled, wide enveloping mucilage absent, cells round to oval, hemispherical after division, intensely blue green or blackish in colour, 17-25 $\mu$ min diameter; granules present, prominent; sheath thin, firm, hyaline or light yellowish, unlamellate or rarely lamellate, sometimes diffluent at the margins. Collected specimens were epilithic. (I)

\section{Chroococcus turicensis (Nageli) Hansgirg}

Colonies microscopic, few celled colonies, gelatinous, diffluent, sometimes composed of subcolonies with 2-4 cells; cells pale blue green or olive green in colour, spherical or oval in shape, 13.5-16 $\mu \mathrm{m}$ in diameter; sheath present, firm, usually unlamellate, rarely lamellate, colourless, sometimes light yellow in colour; granules present. Collected specimens were epilithic. (K)

\section{Chroococcus schizodermaticus West}

Colonies microscopic, usually only 2-4 celled, common mucilage absent or occasionally present, brown in appearance; cells spherical, hemispherical or irregularly rounded, blue-green or pale blue-green in colour, 6.5-10 $\mu \mathrm{m}$ in diameter; sheath firm, thick, wide, yellow or yellowish brown in colour, concentrically lamellate; granules present, prominent. Collected specimens were epilithic. $(\mathrm{H})$

\section{Discussion:-}

Kerala is one of the least explored areas in the case of cyanobacteria. In Kerala, forest regions, especially parts of Western Ghats are almost untouched. Only a single exploration work has been reported from forest regions of Kerala State. Philip et al., (2016) reported 15 species of cyanobacteria coming under 4 families from Nelliyampathy Ghats, Pothundi dam and nearby areas including 3 members from the genus Chroococcus. Other Districts of Kerala has been left pretty much untouched. Anand (1989) studied the diversity of cyanobacteria from paddy fields of South India, which include Kerala. But he did not mention the areas specifically. A study on diazotrophic cyanobacterial association were conducted from the South eastern Arabian sea (Jabir et al., 2013).

The limited studies carried out on cyanobacterial diversity in Kerala were all focused on coastal areas and agricultural lands. The minimal availability of literature shows the importance of study and identification of cyanobacterial forms. internationally taxonomic and biotechnological aspects of cyanobacterial members including Chroococcus is getting updated periodically whereas in our country, it is somehow entirely neglected. Since these microscopic organisms are highly promising, the need of greater focus on cyanobacterial explorations are evident. There are more Chroococcacean species waiting for their discovery and with no doubt, we will introduce many newer members to the cyanobacterial community.

\section{Acknowledgement:-}

I express my gratitude towards Kerala Forest Department and forest watchers for their support. I am also thankful to the Head, Department of Botany, University of Calicut for providing all the necessary facilities during the course of study. Farhad V.P, Arun T. Ram, Swetha K. and Dr. M. Shamina are also specially mentioned here for the help rendered during the course of study. 

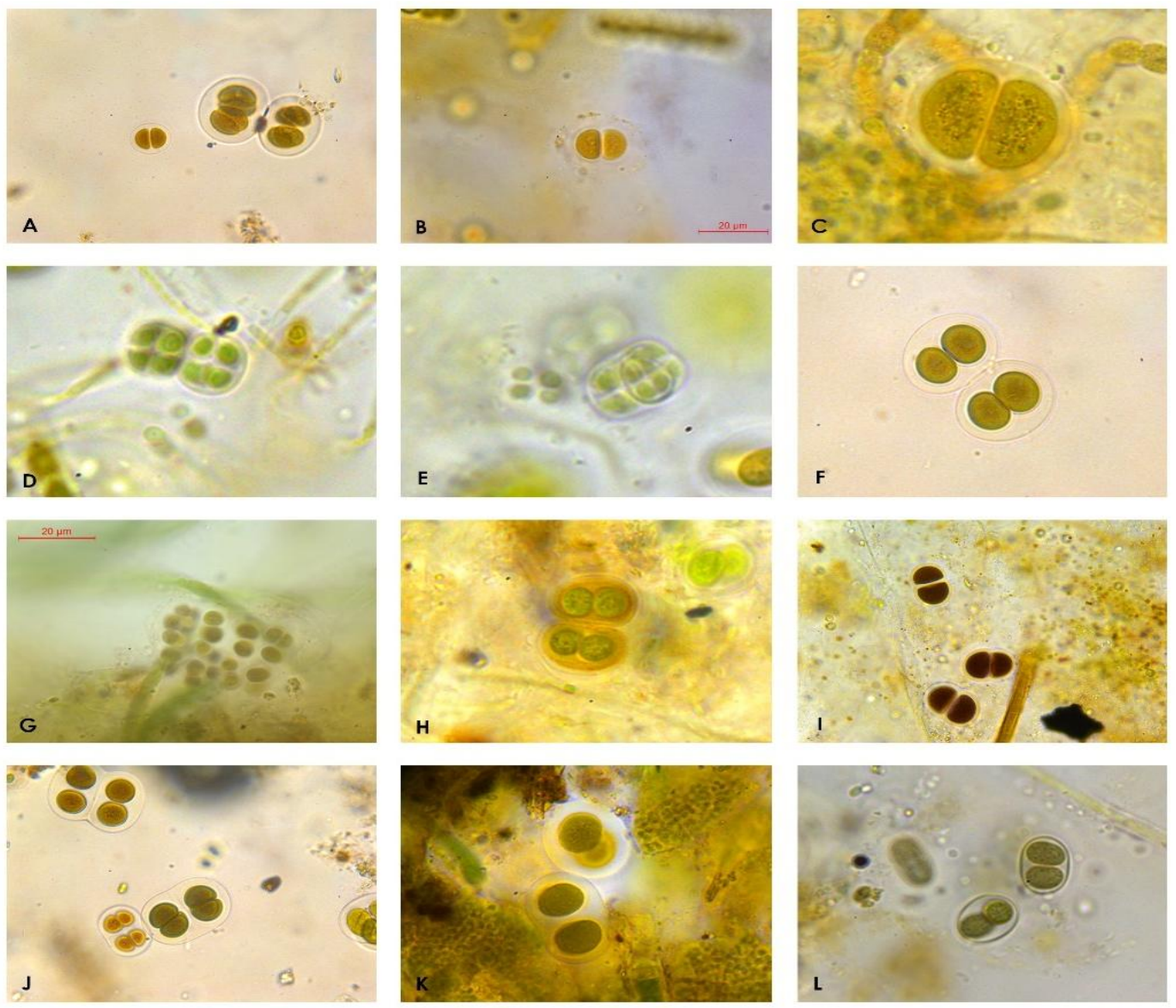
A. Chroococcus cohaerens,
B. Chroococcus minutus,
C. Chroococcus minutus var. thermalis, D \&
E. Chroococcus mipitanensis,
F. Chroococcus pallidus,
G. Chroococcus quaternarius,
H. Chroococ- cus schizodermaticus, I. Chroococcus subnudus, J. Chroococcus turgidus, K. Chroococcus turicensis, L. Chroococcus indicus.

\section{References:-}

1. Anand, N., (1989): Handbook of blue-green algae (of rice field of South India), Bishen Sing Mahendra Pal Sing, 20-45.

2. Desikachary, T.V., (1959): Cyanophyta monographs on algae, Indian Council of Agricultural research, New Delhi, 10-100.

3. Jabir, T., Dhanya, V., Jesmi, Y., Prabhakaran, M.P., Saravanane, N., Gupta, G.V.M. and Hatha, A.A.M. (2013): Occurrence and Distribution of a Diatom-Diazotrophic Cyanobacteria Association during a Trichodesmium Bloom in the Southeastern Arabian Sea. International Journal of Oceanography, 2013: 1-6.

4. Komarek, J., Kastovsky, J., Mares, J. and Johansen, J.R. (2014): Taxonomic classification of cyanoprokaryotes (cyanobacterial genera) 2014, using polyphasic approach. Perslia, 86:195-335.

5. Philip, M., Farhad, V.P., Shamina, M., (2016): Diversity of cyanobacterial flora at Nelliyampathy, Kerala, South Indian Journal for Biological Science (2)1:198-202.

6. Rippka, R., Deruelles, J., Waterburg, J.B., Heedman, M., Stainer, R.Y. (1979): Generic assignments, strain histories and properties of pure cultures of cyanobacteria. Journal of General Microbiology, 111:1-61. 